\title{
The Association between EFL Teachers' Interpersonal Behavior and Students' Achievement in English Language: Selected Secondary Schools in Focus
}

\author{
Abate Demissie Gedamu* and Mohammed Shure
}

Department of English Language and Literature, Arba Minch University, Arba Minch, Ethiopia

\begin{abstract}
This study attempted to map EFL teachers' interpersonal behavior as perceived by students, its relationship with the students' English language achievement, and to examine if it could predict students' English language achievement. The samples of the study were randomly selected 353 grade 9 students from Arba Minch and Chamo Preparatory and Secondary schools in Ethiopia. Data were collected through interpersonal behavior questionnaire and English language achievement test. In order to map teachers' interpersonal behavior, mean and standard deviations of the QTI dimensions were used while multiple regression was used to examine the correlations between teachers' interpersonal behavior and English language achievement test scores. Furthermore, multiple regression was used in order to examine the degree to which EFL teachers' interpersonal behaviors predicted their students' English language achievement score. The findings indicated that understanding was perceived as interpersonal behavior which occurred most often in English language classes followed by leadership, strict and student responsibility/freedom behaviors respectively. Divergently, uncertain behavior was found to be least perceived behavior. With respect to the major dimensions of interpersonal behavior, the result showed that teachers in the sample areas are less dominant but more cooperative over the communication process with their students. Concerning associations, this study found positive and significant correlations between students' English language achievement and their teachers' leadership and understanding behaviors. Regarding the dimensions, both proximity and influence were correlated positively and significantly with students' English language achievement. It was also found that teachers' interpersonal behavior all together explained $6.3 \%$ of the variances in the students' English language achievement scores. Pertaining to the relative contribution of each independent variable, understanding, followed by leadership interpersonal behavior was found to be the most powerful and significant variable on the students' English language achievement while dimension wise, only influence was determining students' English language achievement significantly.

Copyright@2015 STAR Journal, Wollega University. All Rights Reserved.

Article Information Article History:

Received : 18-06-2015

Revised : 27-09-2015

Accepted : 28-09-2015

Keywords:

Interpersonal behavior

Perceived behavior

EFL teachers'

Communication process

Achievement

${ }^{*}$ Corresponding Author:

Abate Demissie Gedamu

E-mail:

abachad22@gmail.com

\section{INTRODUCTION}

English language has been offered as a subject as of grade 1 to the first year of university education in Ethiopia. Moreover, it has been a medium of instruction commencing from second cycle of primary education despite the variations among regional states as to the cut off grade levels. In spite of these efforts, research works indicated that the English language performance of the students has been declining at all levels (Fisher and Swindells, 1998; Girma, 2003; Michel, 2003; Tekeste, 2006 and Amlaku, 2010). With regards to the extent of the problem, Amlaku (2010:10) for instance has the following to say:

Presently, teachers at schools and employers in industries have been complaining about the low level of English language competence of students and graduates respectively. Students who join colleges and universities are unable to express themselves in

English well; graduates who join the world of work fail to write their own CV and application letters for job.

On the same line of discussion, Fisher and Swindells (1998) ascertained that students in higher institutions had difficulties of grasping series of lectures in English. Moreover, it was disclosed that students could not able to carry out academic readings in English to cope with the requirements of tertiary level education. Similar to that of tertiary level, the English language performance of the students at secondary schools has also become an obstruction of the teaching-learning process (Girma, 2003 and Tekeste, 2006). In the same vein, Michel (2003) as cited in Tekeste (2006) found out that students can hardly read in English at the end of the second cycle of primary education. Nevertheless, they are expected to continue their studies in English as it changes from a subject to the medium of instruction in secondary schools.
\end{abstract}




\section{Abate Demissie and Mohammed Shure}

With regards to students' English language performance at primary education level, USAID Ethiopia (2010), as cited in Ethiopian Academy of Sciences (2012), did a study on early grade reading and writing. Accordingly, although students in grades 1-3 have been exposed to three early grade curricula, the finding underlined that the distinctions among these grade levels seem to be blurred in almost all regions. This implies the lack of a minimum standard that distinguishes one grade level from others in early reading and writing.

The few studies reviewed above may give glimpses of the situation of English language in Ethiopia. Accordingly, it seems apparent to conclude that there is a decline in English language performances of students at all levels. Although there could be various variables which influence English language performance of students', teachers are the most important players no matter how pretentious a school system and its curricula may be (Sanders, 1998; Goldhaber, 2002; Akbari and Allvar, 2010; Ethiopian Academy of Sciences, 2012 and Fehintola, 2014).

Since the ultimate goal of language learning or teaching is the development of learners' communicative competence, learners have to be given the opportunity to practice and internalize it particularly in EFL context. To this effect, teacher interpersonal behavior (how teacher interacts with students'), is the heart of the teaching or learning process which in turn determines the students performance (Wubbels et al., 1985; Smith, 1998 and Knapp and Antos, 2009). This is because learning occurs best in an environment of positive interpersonal relationships or interactions in which learners feel appreciated, acknowledged, respected, and admired (McCombs and Whistler, 1997). Furthermore, Hargreaves (1994) underlines the need for interpersonal behavior of teachers in effective teaching-learning processes:

Good teaching is charged with positive emotion. It is not just a matter of knowing one's subject, being efficient, having correct competencies, or learning all the right techniques. Good teachers are not just well oiled machines. They are emotional, passionate beings who connect with their students' and fill their work and classes with pleasure, creativity, challenge and joy (p 835).

Accordingly, it appears that teacher's care, concern and good rapport with the students that ensure smooth functioning of the teaching-learning process are paramount important as content and pedagogical knowledge if not more. Thus, it seems worthy to consider teachers' interpersonal behavior and its relation to students' academic achievement in an effort to make the teacher-learning process more effective and efficient. It is believed that a thorough investigation of the nature of the communication between teachers and students would give teachers a clearer picture of teacher-student interactions (Den Brok and Koopman, 2006 and Fraser, 2010). On the basis of the gained insight, teachers may modify their behaviors to cater more adequately for the needs of students (Fraser, Aldridge and Soerjaningsih, 2001).

With regard to mapping the interpersonal behavior of teachers from students' perspective, studies have been carried out in different parts of the world. Pertaining to the two major dimensions of interpersonal behavior, studies
Sci. Technol. Arts Res. J., July-Sep 2015, 4(3): 222-229

reported that students generally perceived teachers more cooperative than dominant (Wubbels et al., 2006; Telli et al., 2007; Wei, den Brok and Zhou, 2009 and Mulana et al, 2011). Nevertheless, Dutch teachers were perceived lowest on both dimensions while Bruneian teachers were conversely perceived highest on the influence dimension as cited in (Wubbels et al., 2006 and Telli et al., 2007).

Specific to the sub-dimensions, the major prevailing interpersonal behaviors of secondary teachers in Australia, Singapore and Brunei as perceived by students were found to be friendly, understanding and leadership (Den Brok et al., 2003). Similarly, a study done by Wei, Brok and Zhou (2009) indicated that understanding behavior of teachers' was perceived most frequent while uncertain was the least by students at secondary schools in Chinese EFL classrooms. Divergent to the studies discussed above, all eight types of teacher interpersonal behaviors were found with similar frequencies of occurrence in Netherlands and American classrooms (Den Brok et al., 2003).

Concerning the relationship between teachers' interpersonal behavior and their students' academic performance, research works have been reviewed too. Accordingly, den Brok, Brekelmans and Wubbels (2004) indicated that students' perception of teachers' influence related positively with their test results. On the other hand, studies also found associations between proximity and cognitive outcomes (Henderson, 1995 and Evans, 1998). However, inconsistent to the studies mentioned above, no significant correlation was found between the two dimensions and cognitive outcomes (Wubbels, Brekelmans, den Brok and van Tartwijk, 2006 and Wei, Brok and Zhou, 2009). Particular to the sub-dimensions, according to some studies strict, leadership, understanding and friendly behaviors were positively related to students' achievement while student freedom, uncertain, dissatisfied and admonishing behaviors were found negatively related to the students' achievement (Wubbels, 1993; Rickards and Fisher, 1996; Smith, 1998 and Fraser, Aldridge and Soerjaningsih, 2001). Surprisingly, in study done by Wei, Brok and Zhou (2009), only uncertainty was correlated negatively and significantly with students' English language achievement in China.

Finally, studies were conducted on the degree to which students' perception of their teachers interpersonal behaviors could predict students' academic achievement. Accordingly, students' perception of their teachers' interpersonal behaviors roughly accounted for 10\% $(\mathrm{F}=14.220, p<0.005)$ of the variances in mathematics achievement of the students in Turkish secondary school (Simseker, 2005). Specific to the relative contribution of the independent variable, only leadership, understanding, uncertain and strict behaviors were found predicting students' achievement significantly (Simseker, 2005). On the same lines of discussion, Fraser, Aldridge and Soerjaningsih (2001) found that only strict scale was contributing significant amount of variance on the students' achievement score. Concerning dimensions, teachers' proximity with students was the only significant predictor of the students' English language achievement although the extent of variance is small (Wei, Brok and Zhou, 2009). Divergently, influence was found determining students' academic performance significantly 


\section{Abate Demissie and Mohammed Shure}

in the work done by den Brok, Levy, Brekelmans and Wubbels (2006).

The preceding studies indicated empirical evidences of teacher interpersonal behaviors, relationships between these behaviors and students' achievement, and the degree to which teachers' interpersonal behaviors predicted students' academic achievement. However, the findings indicated variations among countries due to the fact that perception and communication are culturally influenced (Levy, Wubbels, Brekelmans, and Morganfield, 1997 and Rickards and Fisher, 2000). In addition, the findings are contradictory instead of being conclusive. Furthermore, perception of interpersonal behavior is influenced by student and teacher ethnic background, class size, and specific subject under the study (Levy, Wubbels, Brekelmans and Morganfield, 1997; and Den Brok, Fisher, and Rickards, 2004). Consequently, the findings made elsewhere may not be applicable to Ethiopian situation. Therefore, it seems that empirical evidence on EFL teachers' interpersonal behavior and its relation to the students' English language achievement is lacking. Thus, this study attempted to fill this gap and contribute towards our understanding of the situation. More specifically, the study was intended to answer the following specific research questions:

(1) How do students perceive their current EFL teachers' interpersonal behaviors?

(2) What relationships exist between EFL teachers' interpersonal behaviors and the students' English language achievement?

(3) To what extent do EFL teachers' interpersonal behaviors predict the students' English language achievement?
Sci. Technol. Arts Res. J., July-Sep 2015, 4(3): 222-229

It is hoped that the results of this study could provide EFL teachers with awareness of their interpersonal behaviors as perceived by the students. On the basis of this awareness, teachers may reflect on and optimize teacher-student relationships. This in turn may create conducive classroom conditions that enhance students' academic achievement in English. Furthermore, the finding may provide teacher training institutions with empirical evidence of EFL teachers' interpersonal behavior and its relationship to students' learning. Consequently, the institutions may take the outcomes into their teacher preparation programs if need be. Finally, the outcome of this study may also motivate teachers and other stakeholders to investigate on the same or similar variables that influence students' English language achievement

\section{Theoretical Framework}

Inspired by Leary's communication theory (1957) and Watzlawick, Beavin and Jackson's human communication theory (1967), Wubbels, Créton, and Hooymayers (1985) developed a model to map teacher-student interpersonal behaviors. Accordingly, the behaviors of teachers were plotted along two axes- influence dimension (Dominance Submission, DS) and a proximity dimension (Cooperation - Opposition, CO) as shown below. According to Wubbels, Créton, and Hooymayers (1985), the influence dimension portrays who is controlling or directing the communication process and how often; and the proximity dimension indicates the degree of cooperation or closeness in the process of communication. These scholars argued that both dimensions are independent and evocative of effective teacher behaviors that could influence classroom processes (Figure 1).

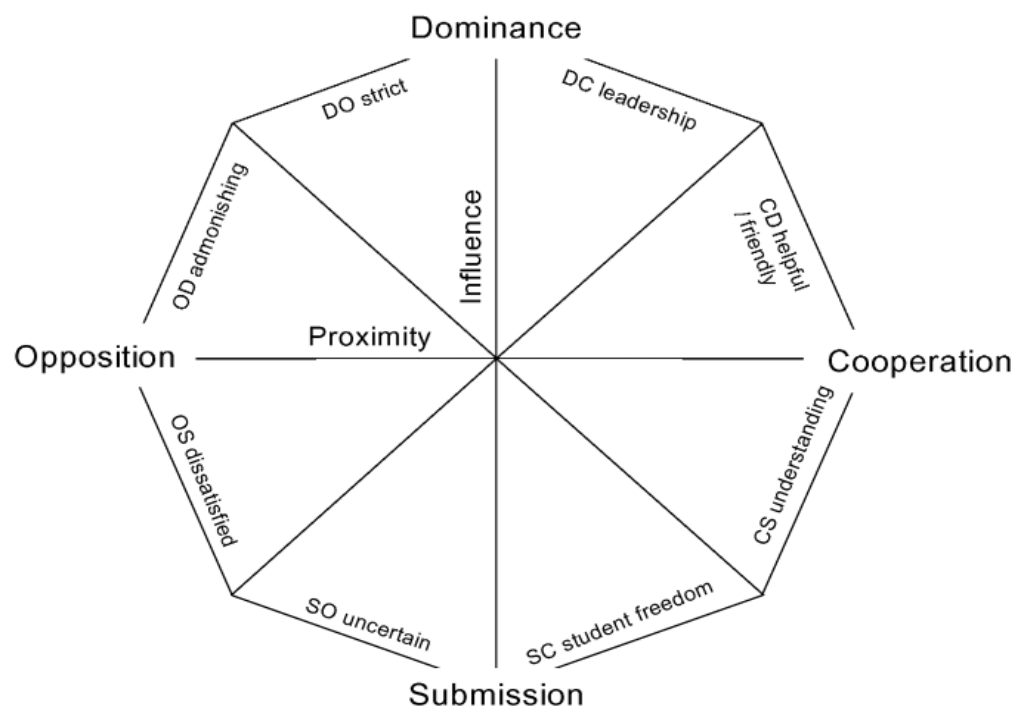

Figure 1: The Wubbel's model for teacher interpersonal behavior as in Fisher and Rickards (1998)

The two dimensions structure every teacher's behavior and can be used to subdivide interpersonal behavior in eight sectors, each describing different aspects of interpersonal behavior (Wubbels et al., 1985). The sections are labeled as DC, CD, CS, SC, SO, OS, OD and DO according to their positions in the coordinate system. For example, the two sectors DC and CD are both characterized dominance and cooperation. In the DC sector, however, the dominance aspect prevails over the cooperation aspect, where as in the adjacent sector CD cooperation prevails over the dominance aspect (Wubbels, Créton, Levy and Hooymayers, 1993). The eight coded sectors are labeled as leadership, helping/ friendly, understanding, student responsibility/ freedom, uncertain, admonishing, dissatisfied, and strict behaviors respectively. 
Abate Demissie and Mohammed Shure

Wubbel's et al. (1993) provided a description of typical teacher behaviors belonging to each of the eight sectors. Accordingly, the leadership (DC) teachers notice what's happening, lead, organize, give orders and determine procedure, and structure the classroom situation, explain and hold attention. Similarly, the helpful/friendly (CD) teachers show interest, behave in a friendly or considerate manner and inspire confidence and trust whilst understanding (CS) teachers show confidence and understanding and are open with students. Moreover, the teachers listen with interest, empathize, accept apologies, look for ways to settle differences and be patient. By the same token, the student responsibility/freedom (SC) teachers give opportunity for independent work; give freedom and responsibility to students. On the contrary, the uncertain (SO) teachers behave in an uncertain manner and keep a low profile, apologize, wait and see how the wind blows. On the other hand, the strict (DO) teachers keep the reins tight, get the class silent, maintain silence, exact norms and set rules. The dissatisfied (OS) teachers express dissatisfaction, look unhappy, criticize, consider pros and cons, look glum, question and wait for silence while teachers in admonishing (OD) sector get angry, express irritation and anger, forbid and punish.

Consequently, this study adopted the model developed by Wubbels, Créton, and Hooymayers (1985) in order to map teacher-student interactions. Moreover, it should be noted that the standardized Questionnaire on Teacher Interaction (QTI) that has been used for this study was developed based on this model.

\section{MATERIALS AND METHODS}

\section{The Research Design}

This study attempted to investigate mainly the association between EFL teachers' interpersonal behaviors and students' English language achievement. Moreover, it was to examine if EFL teachers' interpersonal behaviors could predict students' English language achievement without necessarily manipulating the independent variables. Therefore, this study adopted descriptive research design of correlation type.

\section{The Sample of the Study}

The target population of this study was Grade 9 students at Arba Minch and Chamo Secondary and Preparatory Schools in 2014/15 academic year. The schools were selected on the basis of their convenience for data collection as they are located in Arba Minch Town where the researchers live. Grade 9 students were chosen for the study purposively because they were new to the schools and to their English language teachers as compared to other grade level students who already made adjustment to the situations. Thus, it was hoped that these students perception of student-teacher relationship and its felt effect with academic achievement may give different picture than those who already adjusted to the situations.

Since it is difficult to take all the students of this grade level, 180 grade 9 students from each school were taken through systematic random sampling technique as this technique can give all students equal probability of selection. Thus, the total sample of the study constituted 360 students. However, only 353 students filled QTI completely and properly. Thus, the study was carried out with data from 353 students on the interpersonal behaviors of $19 \mathrm{EFL}$ teachers.
Sci. Technol. Arts Res. J., July-Sep 2015, 4(3): 222-229

\section{Variables in the Study}

The major independent variable in the study is EFL teachers' interpersonal behavior as perceived by their students. The interpersonal behavior has proximity and influence as major dimensions with eight subscales as measured through QTI. The subscales are leadership, helping/friendly, understanding, uncertain, dissatisfied, admonishing, strict and student responsibility/freedom behaviors. The dependent variable is English language achievement mean score of the students that was obtained through test.

\section{Data Collection Instruments \\ Achievement Test}

To acquire the students' English language achievement, a test consisting of 30 multiple choice items on reading comprehension, vocabulary and grammar sections were developed from chapters covered. In addition, the test had paragraph writing section in order to test their writing skill. The test was piloted on nonsample students of the same level to determine the internal consistency of the items. Accordingly, an acceptable Cronbach alpha value of 0.79 was found for multiple choice items

\section{Questionnaire on Teacher Interaction (QTI)}

Students spend a vast amount of time in school classrooms. Moreover, their perceptions are often based on a large number of lessons. Consequently, they seem quite able to perceive and weigh classroom stimuli and render valid judgments on characteristics of their classrooms (Shuell, 1996 and Fraser 1998). To this effect, data on EFL teachers' interpersonal behavior was gathered using the standardized Questionnaire on Teacher Interaction QTI (Wubbels et.al, 1993).

The Questionnaire on Teacher Interaction (Wubbels et al., 1993) consists of 48 items. These items are divided into eight scales which conform to the eight sectors of the model. The eight domains are: leadership, understanding, helpful/ friendly, dissatisfied, admonishing, strict, uncertain, and student/ responsibility/ freedom. Each domain contained six items with a five-point scale (1-5) with the extreme alternatives of Never-Always.

The QTI has been shown to be a valid and reliable instrument (Den Brok, Wubbels and Rodriguez, 2003 and Wubbels et al., 1993). Moreover, it has been proved to be useful for mapping teachers' interpersonal behaviors that are transferable to different cultural conditions (Wubbels et al., 1993 and Mulana et al., 2011). In order to let the students fill the questionnaire easily, the English version of the instrument was translated into Amharic by translation experts. Furthermore, the translation was checked by two Amharic instructors to ensure that each item retained its original meaning. Nonetheless, the reliability of the instrument was carried out for the current study. To this effect, it was found that the reliabilities range from 0.64-0.86: (0.74) uncertain, (0.72) strict, (0.81) leadership, (0.84) understanding and (0.64) student responsibility/ freedom. Three scales, namely admonishing, helpful/friendly and dissatisfied behaviors were eliminated due to their high correlations with their respective adjacent behavior. The eliminations of these three variables reduced the effect of multi-linearity on regression model. 
Abate Demissie and Mohammed Shure

\section{Procedures}

Prior to data collection event, all students were informed that their responses to QTI would be kept confidential and would not affect their English grades. Having assured this; the QTI was administered to probe their perceptions of EFL teachers' interactions occurring in the classroom. Subsequently, English language achievement test was administered to the participants. Additionally, it was assumed that the students responded to the Questionnaire on Teacher Interaction (QTI) honestly provided that anonymity of the data being assured. Moreover, the situations under which the samples responded to each instrument at both sites were similar.

\section{Methods of Data Analysis}

To analyze and interpret the data that were acquired through QTI and English language achievement test, both descriptive and inferential statistics were used. Accordingly, the Statistical Package for the Social Sciences (SPSS) version 20 was put in practice. In order to map teachers' interpersonal behavior, mean and standard deviations of the QTI dimensions were employes. To investigate correlations between teachers' interpersonal behavior and English language achievement test scores, multiple regression was applied at a significant level of 0.05 .

In addition, in order to examine the degree to which EFL teachers' interpersonal behavior influenced the students' English language achievement score, multiple regression was employed. Furthermore, standardized multiple regression coefficients $(\beta)$ were utilized to determine the scales which contributed uniquely and significantly to the explanation of the variances in the dependent variable. It should be noted that data were checked against the assumptions of regression before running SPSS.

\section{RESULTS}

As it is indicated in table 1 , most of the students perceived understanding as an interpersonal behavior that often took place in their English language classrooms $(M=4.54, S D=0.54)$ followed by leadership $(\mathrm{M}=4.00, \mathrm{SD}=1.04)$, strict $(\mathrm{M}=3.07, \mathrm{SD}=0.92)$ and student freedom $(M=2.90, S D=1.33)$ respectively. The scale which rarely took place in students' classrooms was uncertain $(M=2.21, S D=1.41)$. Pertaining to the major dimensions of interpersonal behavior, as depicted in the table, the students perceived their teachers as more proximal to them $(M=1.25, \quad S D=0.67)$ than influential $(M=0.34$, $S D=0.36$ ) though both are apparent behaviors of the teachers.

Table 1: EFL Teachers Interpersonal Behavior as Perceived by the Students

\begin{tabular}{lcc}
\hline $\begin{array}{c}\text { Teacher Behavior } \\
\text { Dimensions }\end{array}$ & Mean & $\begin{array}{c}\text { Std } \\
\text { deviation }\end{array}$ \\
\hline Understanding & 4.54 & 0.54 \\
Leadership & 4.00 & 1.04 \\
Strict & 3.07 & 0.92 \\
Student Freedom & 2.90 & 1.33 \\
Uncertain & 2.21 & 1.41 \\
Influence & 0.34 & 0.36 \\
Proximity & 1.25 & 0.67 \\
\hline
\end{tabular}

Sci. Technol. Arts Res. J., July-Sep 2015, 4(3): 222-229

As shown in table 2 above, students' English language achievement had significant correlations with their teachers' leadership $(r=0.158, p<0.01)$ and understanding $(r=0.178, \quad p<0.01)$ behaviors. On the contrary, the correlations were non-significant for strict $(r=0.023$, $p>0.05)$, student freedom $(r=0.065, \quad p>0.05)$ and uncertain $(r=-0.011, p>0.05)$ behaviors of the teachers. Regarding the two dimensions of interpersonal behaviors, positive and significant correlations were found between students' English language achievement and influence ( $r=$ $0.116, p<0.05) \&$ proximity $(r=0.098, p<0.05)$ respectively.

Table 2: The Associations of QTI scales / dimensions with students' English language achievement

\begin{tabular}{lcc}
\hline Scale/Dimension & $\mathbf{r}$ & $\mathbf{p}$ \\
\hline Leadership & 0.158 & 0.001 \\
Understanding & 0.178 & 0.000 \\
Strict & 0.023 & 0.33 \\
Student Freedom & 0.065 & 0.11 \\
Uncertain & -0.011 & 0.42 \\
Influence & 0.116 & 0.015 \\
Proximity & 0.098 & 0.032 \\
\hline
\end{tabular}

Table 3 shows the combined effect of the five independent variables to the dependent variable. Accordingly, students' English language achievement correlated positively and significantly with the five predictor variables with a coefficient of multiple correlations (R) of 0.276 and adjusted $R$ square of 0.063 This implies that $6.3 \%$ of the variance in the students' English language achievement is accounted for by the five predictor variables. This joint contribution of the independent variables to the dependent variables was significant $(F(5,347)=5.729, p<0.001)$.

Table 3: The combined prediction of students' Academic Achievement by the independent variables

\begin{tabular}{|c|c|c|c|c|c|}
\hline Source & S S & DF & MS & $\mathbf{F}$ & Sig \\
\hline Regression & 17.217 & 5 & 3.443 & 5.729 & 0.000 \\
\hline Residual & 208.557 & 347 & 0.601 & & \\
\hline Total & 225.775 & 352 & & & \\
\hline \multicolumn{6}{|c|}{ Multiple $\mathrm{R}=0.276$, Adjusted $\mathrm{R}^{2}=0.063$} \\
\hline
\end{tabular}

Table 4 divulges the relative contribution of the five independent subscales and the two major dimensions to the dependent variable. Accordingly, as indicated by the standardized regression coefficient $(\beta)$, perceived understanding behavior made the most significant relative contribution to the prediction of English language achievement $(\beta=0.937, t=3.838, \quad p<0.01)$ followed by leadership behavior $(\beta=0.492, t=2.408, p<0.05)$. However, strict $(\beta=-0.305, t=-1.424, p>0.05)$, student freedom $(\beta=$ $0.049, \mathrm{t}=-0.289, p>0.05)$ and uncertain behaviors $(\beta=$ $0.026, t=-0.199, p>0.05)$ were not significant predictors of English language achievement of the students in the sample secondary schools in SNNPS, Ethiopia. Concerning the two dimensions, influence $(\beta=0.116, t=$ $2.190, p<0.05)$ was found to be significant predictor of English language achievement of the students while proximity $(\beta=0.098, t=1.854, p>0.05)$ behavior was found to be non-significant predictor. 
Abate Demissie and Mohammed Shure

Table 4: Relative contribution of the independent variable to English language Achievement

\begin{tabular}{lccc}
\hline Predictor Variables & $\boldsymbol{\beta}$ - weight & $\mathbf{t}$ & $\boldsymbol{p}$ \\
\hline Constant & & -2.031 & 0.43 \\
Leadership & 0.492 & 2.408 & 0.017 \\
Understanding & 0.937 & 3.838 & 0.000 \\
Strict & -0.305 & -1.424 & 0.155 \\
Student Freedom & -0.049 & -0.289 & 0.773 \\
Uncertain & -0.026 & -0.199 & 0.842 \\
Influence & 0.116 & 2.190 & 0.029 \\
Proximity & 0.098 & 1.854 & 0.065 \\
\hline
\end{tabular}

\section{DISCUSSION}

The objectives of this study were to map EFL teachers' interpersonal behavior, investigate the relationship between the teachers' interpersonal behavior and students' English language achievement, and to examine if interpersonal behavior could predict students' English language achievement. To begin with, the first objective was to map EFL teachers' interpersonal behaviors as perceived by their students. Accordingly, understanding, followed by leadership was perceived as interpersonal behavior which occurred most often in English language classes. Next to this, the students perceived strict and student responsibility/freedom as other behaviors of their teachers implying that teachers display strict behavior on one hand and give responsibility for independent work or freedom to their students on the other hand. Divergently, uncertain behavior was found to be least perceived which means that teachers display this behavior rarely. This finding is harmonious with the findings of Wei, den Brok and Zhou (2009) where understanding behavior of EFL teachers' was perceived most while uncertain was the least by Chinese students at secondary schools. However, this study's finding is different from study done in Netherlands and American classrooms where all eight types of teacher interpersonal behaviors were found with similar frequencies of occurrence (Den Brok et al., 2003).

With respect to the major dimensions of interpersonal behavior, the mean results of the two dimensions show that students perceived their teachers more cooperative than dominant in their behavior though both characterized the teachers as moderately dominant and very cooperative. This is in accord with previously done works that students generally perceive teachers more cooperative than dominant (Wubbels et al., 2006; Telli et al., 2007; Wei, den Brok and Zhou, 2009 and Mulana et al, 2011). As compared to similar works elsewhere, the mean value of influence $(M=0.34, S D=0.36)$ of this study was found to be smaller than the mean in China, Singapore, Australian and India (Wei, den Brok and Zhou, 2009). Divergently, Proximity (CO) mean score ( $M=1.25$, $S D=0.67$ ) of this study was found to be bigger than the four countries cited above. This may imply that Ethiopian teachers in the sample areas are less dominant but more cooperative over the communication process with their students as compared to teachers in countries cited above.

Concerning associations, this study found positive and significant correlations between students' English language achievement and their teachers' leadership and understanding behaviors. The finding implies that the students' English language achievements increase as their perceptions of their teachers leadership and
Sci. Technol. Arts Res. J., July-Sep 2015, 4(3): 222-229

understanding behaviors increase. Conversely, no significant correlations were found between English language achievement of the students and their teachers' strict, student freedom and uncertain behaviors. This finding is partly consistent to Wubbels and Brekelmans (1998) and Wubbels et al (2006) where leadership and understanding behaviors were correlated significantly with the students' English language achievement. However, it disagrees with Wei, Brok and Zhou (2009) where only uncertainty was correlated negatively and significantly with students' English language achievement. Regarding the two dimensions, both proximity and influence were correlated positively and significantly with students' English language achievement. The finding of the current study is consistent with previous works (Henderson, 1995; Evans, 1998 and den Brok, Brekelmans and Wubbels, 2004). However, it is incompatible with some other works where no significant correlations were found between the two dimensions and students' cognitive achievement (Wubbels, Brekelmans, den Brok and van Tartwijk, 2006 and Wei, den Brok and Zhou, 2009).

In addition, the study found that the five predictor variables in combination correlated positively and significantly with the students' English language achievement $(\mathrm{R}=0.276, \quad p<0.001)$. Moreover, the behaviors in combination predicted students' English language achievement significantly $\left(R^{2}=0.063, p=0.000\right)$. This implies teachers' interpersonal behaviors all together explained $6.3 \%$ of the variances in the students' English language achievement scores. The amount of the effect observed in this study is almost close to the $10 \%$ $(\mathrm{F}=14.220, p<0.005)$ of the variances in mathematics achievement of the students in Turkish secondary school (Simseker, 2005). Pertaining to the relative contribution of each independent variable, understanding, followed by leadership interpersonal behavior was found to be the most powerful and significant predictor of the students' English language achievement. On the same line of discussion, Simseker (2005) study indicated that understanding and leadership interpersonal behaviors were predicting students' achievement significantly though they were not the only. In contrast, Fraser, Aldridge and Soerjaningsih (2001) found out that only strict scale was contributing significant amount of variance to the students' achievement score. Dimension wise, the finding of the current study confirmed that only influence was found determining students' English language achievement significantly. This finding is in agreement with done by den Brok, Levy, Brekelmans and Wubbels (2006) while it is opposite with the finding made by Wei, Brok and Zhou (2009) in which influence was found determining students' academic performance significantly although the extent of variance is small.

\section{CONCLUSIONS}

The results of the current study pointed out that sample EFL teachers in Ethiopian secondary schools display strong understanding and leadership behaviors followed by strict, student responsibility/freedom and low uncertain behaviors. Thus, these teachers exhibited more cooperative (understanding, leadership and student responsibility/freedom) and less dominant (strict behavior) though uncertain behavior was also noticed to some extent. Results also indicated positive and significant correlation between the English language achievement of the students and the understanding and leadership behaviors of their teachers. Similarly, both proximity and 
Abate Demissie and Mohammed Shure

influence were correlated positively and significantly with students' English language achievement as well.

Though there are many factors responsible for students' English language achievement, this study revealed that teachers' interpersonal behavior all together significantly explained $6.3 \%$ of differences on the students' English language achievement scores. Despite the fact that the effect is small, due attention should be given to it since it has potential in determining the students' English language achievement which has been declining at all levels of education. Among the five subscales of interpersonal behavior, this study disclosed that understanding and leadership behaviors were found to be significant predictors of the students' English language achievement. Results also indicated that influence was found to be a significant predictor of the students' English language achievement while proximity was not.

To sum up, the study indicated that students' perception of their EFL teachers' interpersonal behavior has potential to determine their academic achievement to some extent. Therefore, this study suggests that EFL teachers should evaluate their relation with their students to optimize teacher-student relationships in order to create conducive EFL classroom that enhance students' learning. Furthermore, teacher training institutions should provide their trainees with both theoretical and practical orientations on interpersonal behavior and its relationship to students' learning.

There were several limitations of this study. The first limitation was that the study focused on only grade 9 students of two secondary schools at Arba Minch Town, Ethiopia. The finding may not be generalized to teachers and students of other grade levels and schools. In addition, this study used only perception questionnaire on interpersonal behavior solely on students' perspectives and English language achievement test. A similar study on comparisons between students' and teachers' perceptions in the aspects of teacher interpersonal behavior could also be conducted so as to provide a better picture of the real interpersonal behavior of the English language teachers. Furthermore, it will be effective if Qualitative data like observation and interview will be used to understand and explain students'/ teachers' perceptions of teacher- student interpersonal behavior.

\section{Conflict of Interest}

Authors declared no conflict of interest.

\section{Acknowledgement}

I would like to acknowledge Arba Minch University for providing financial support in carrying out this study. In addition, I would like to thank students and other people who were cooperative and helpful during the data collection processes.

\section{REFERENCES}

Akbari, R. and N. Allvar. (2010). L2 Teacher Characteristics as Predictors of Students' Academic Achievement. Journal for English as a Second Language 13(4).

Aldridge, J., Fraser, B.J., and Soerjaningsih, W. (2001). Teacher-student interpersonal behavior and student outcomes among university students in Indonesia. Paper presented at the annual conference of the Australian
Sci. Technol. Arts Res. J., July-Sep 2015, 4(3): 222-229

Association for Research in Education, Fremantle, Australia.

Amlaku Eshetie. (2010). Language Policies and the Role of English in Ethiopia. A presentation paper at the $23^{\text {rd }}$ Annual Conference of IATEFL BESIG (19-21 Nov. 2010), Bielefeld, Germany.

Den Brok, P., Brekelmans, M. and Wubbels, T. (2004) Interpersonal teacher behaviour and student outcomes. School Effectiveness and School Improvement 15: 407442.

Den Brok, P., Levy, J., Wubbels, Th., and Rodriguez, M. (2003). Cultural influences on students' perceptions of videotaped lessons. International Journal of Intercultural Relations 27: 355-374.

Den Brok, P., Fisher, D., and Rickards, T. (2004, April) Predicting Australian Students' Perceptions Of Their Teacher Interpersonal Behavior. Paper presented at the annual meeting of the American Educational Research Association, San Diego.

Den Brok, P., Levy, J., Brekelmans, M., and Wubbels, T. (2005). The effect of teacher interpersonal behavior on students' subject-specific motivation. Journal of Classroom Interaction 40(2): 20-33.

Den Brok, P., Fisher, D., Wubbels, T., Brekelmans, M., and Rickards, T. (2006). Secondary teachers' interpersonal behavior in Singapore, Brunei and Australia: A crossnational comparison. Asia-Pacific Journal of Education 26(1): 79-95.

Ethiopian Academy of Sciences. (2012). Workshop Report on Quality of Education in Ethiopia sponsored by the Royal Society, UK - Pfizer African Academies Program. Addis Ababa, Semien Hotel.

Evans, H. M. (1998). A study of students' cultural background and teacher-student interpersonal behavior in secondary science classrooms in Australia. Unpublished doctoral thesis, Science and Mathematics Education Centre, Curtin University of Technology, Perth, Australia.

Fehintola, J.O. (2014). Teachers' Characteristics as Correlates of Students' Academic Performance among Secondary School Students in Saki-west Local Government Area of Oyo State. Journal of Educational and Social Research 4(6).

Fisher, R. and Swindells, D. (1998). The development priorities of Ethiopian higher education teachers. Journal of In-service Education 24(2): 307-315.

Fraser, B.J. (1998). Classroom environment instruments: Development, validity and applications. Learning Environments Research 1: 7-33.

Girma Gezehagne (2003). In-Service English Language Teacher's Perceptions of the Factors that Influence of Group work Activities in ELT Classes. The Ethiopian Journal of Education XXI: 1.

Goldhaber, D. (2002). The mystery of good teaching: Surveying the evidence on student achievement and teachers' characteristics. Education Next 2(1): 50-55

Hargreaves, A. (1994). Changing teachers, changing times: Teacher's work and culture in the postmodern age. New York: Teachers College Press.

Henderson, D.G. (1995). A study of the classroom and laboratory environments and student attitude and achievement in senior secondary biology classes. Unpublished doctoral thesis, Science and Mathematics 


\section{Abate Demissie and Mohammed Shure}

Education Centre, Curtin University of Technology, Perth, Australia.

Knapp, K., and Antos, G. (2009). Handbooks of Applied Linguistics Communication Competence Language and Communication Problems Practical Solutions (Volume 6). Berlin: Walter de Gruyter $\mathrm{GmbH}$ and Co.

Knoell, C. (2012 ). The Role of Student-teacher Relationship in the Lives of fifth Graders: A Mixed Methods Analysis. A Dissertation Presented to the Faculty of The Graduate College at the University of Nebraska In Partial Fulfillment of Requirements For the Degree of Doctor of Philosophy.

Levy, J., Créton, H., and Wubbels, T. (1993). Perceptions of interpersonal teacher behaviour. In T. Wubbels, and J. Levy, (Eds.), Do you know what you look like? Interpersonal relationships in education (pp. 29-45). London: Falmer Press.

Levy, J., Wubbels, T., Brekelmans, M., and Morganfield, B. (1997). Language and cultural factors in students' percepti ons of teacher communication style. International Journal of Intercultural Relations 21: 29-56.

McCombs, B., and Whisler, J. (1997). The learner-centered classroom and schools: Strategies for enhancing student motivation and achievement. San Francisco, CA: JosseyBass.

Mulana, R, Opdenakker, M., den Brokb and Bosker. (2011) Teacher-student interpersonal relationships in Indonesia: profiles and importance to student motivation. Asia Pacific Journal of Education 31(1): 33-49.

Rickards, T., and Fisher, D. (2000). Three perspectives on perceptions of teacher-student interaction: A seed for change in science teaching. The annual meeting of the National Association for Research in Science Teaching, New Orleans, Louisiana.

Rickards, T.W, Fisher, D.L., and Fraser, B.J., (1996). Gender and Cultural Differences In Teacher-Student Interpersonal Behavior. Paper presented at the Conference of the Educational Research Association, Singapore and the Australian Association of Research in Education. Singapore.
Sci. Technol. Arts Res. J., July-Sep 2015, 4(3): 222-229

Rickards, T., den Den Brok, P. and Fisher, D. (2003). What does the Australian teacher look like? Australian typologies for teacher-student interpersonal behaviour. Proceedings Western Australian Institute for Educational Research Forum, 2003.

Sanders, W. L. (1998). Value added assessment. School Administrator 11(55): 24-27.

Şimsker, M. (2005). Eights Grade Students' Perceptions Related to their Mathematics Teachers' Interpersonal behaviors. M.A Thesis, Middle East Technical University.

Shuell, T.J. (1996). Teaching and learning in a classroom context. In D. C. Berliner and R. C. Calfee (Eds.), Handbook of educational psychology (pp. 726-764). New York: Macmillan.

Smith, W. (1998). Student Perceptions of their Biology Teachers' Interpersonal Teaching Behaviors and Students Achievement and Affective Learning Outcomes.

Tekeste Negash (2006). Education in Ethiopia: From Crisis to the Brink of Collapse. Elanders Gotab AB: Stockholm.

Telli, S., den Brok, P., and Cakiroglu, J. (2007). Students' perceptions of science teachers' interpersonal behavior in secondary schools: Development of a Turkish version of the Questionnaire on Teacher Interaction. Learning Environments Research 10: 115-129.

Wei, M., den Brok and Y. Zhou. (2009). Teacher interpersonal behavior and student achievement in English as a Foreign Language classroom in China. Learning Environment Research 12:157-174.

Wubbels, Th., Creton, H. and Hooymayers, H. (1985) Discipline problems of beginning teachers. Paper presented at annual meeting of American Educational Research Association, Chicago, IL. (ERIC Document 260040).

Wubbels, Th., Brekelmans, M., den Brok, P., and van Tartwijk, J. (2006). An interpersonal perspective on classroom management in secondary classrooms in the Netherlands. In: C. Evertson and C.S. Weinstein (Eds.), Handbook of classroom management: Research, practice and contemporary issues (pp. 1161-1191). New York: Lawrence Erlbaum Associates. 